Original Research

\title{
Effect of Mineral Additives on Fusion Behavior of Agricultural Residue Ashes during Combustion or Co-combustion with Lignite
}

\author{
Despina Vamvuka *, Maria Deli, Antonios Stratakis
}

School of Mineral Resources Engineering, Technical University of Crete, Chania 73100, Greece; EMails: vamvuka@mred.tuc.gr; delhmaria@hotmail.com; astratak@mred.tuc.gr

* Correspondence: Despina Vamvuka; E-Mail: vamvuka@mred.tuc.gr

Academic Editor: Alfonso Chinnici

Journal of Energy and Power Technology

2021, volume 3 , issue 4

doi:10.21926/jept.2104047
Received: September 06, 2021

Accepted: October 29, 2021

Published: November 11, 2021

\begin{abstract}
In this work, the ash fusibility behaviour of selected agricultural residues and their blends with lignite was studied, by carrying out chemical, mineralogical, fusibility and thermogravimetric analyses and calculating slagging/fouling indicators for predicting deposition tendencies in boilers. Two additives, bauxite, and clinochlore, were used at varying amounts to reduce ash melting, followed by examining their anti-fusion mechanisms. Initial deformation and softening temperatures of biomass materials were low for combustion processes operating above $900{ }^{\circ} \mathrm{C}$ due to their high concentration in $\mathrm{K}, \mathrm{Na}$, and $\mathrm{P}$ compounds. When the additives were mixed with raw fuels or lignite/biomass blends, the initial deformation of ashes started at temperatures up to $340{ }^{\circ} \mathrm{C}$ higher, whereas the fluid temperature in most cases exceeded $1500{ }^{\circ} \mathrm{C}$. Bauxite was more effective than clinochlore. The positive impact of additives was attributed to the mineralogical transformations during ashing to phases with a high melting point through reactions with $\mathrm{K}$, Na-bearing minerals, or $\mathrm{CaO}$ of fuel ashes.
\end{abstract}

\section{Keywords}

Ash; fusion; additives; fouling; biomass; lignite

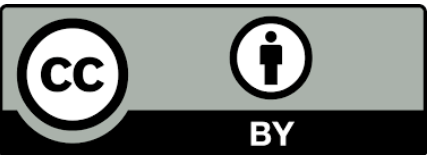

(c) 2021 by the author. This is an open access article distributed under the conditions of the Creative Commons by Attribution License, which permits unrestricted use, distribution, and reproduction in any medium or format, provided the original work is correctly cited. 


\section{Introduction}

Renewable energy sources are increasingly being used worldwide to replace the fossil fuel reserves declining rapidly and reduce environmental emissions. Biomass contributes the highest share to heat and power generation because of its widespread availability in nearly all countries, low cost, and carbon-neutral [1, 2]. Although high-quality woody materials have been traditionally used in the energy sector, they are recently preferred to generate liquid biofuels and chemicals [3, 4], thus increasing their prices and reducing their availability for combustion applications. Consequently, residual biomass, such as agricultural wastes or naturally grown energy crops, which are abundantly found globally could meet the European Union Agricultural and Renewables Policy $[5,6]$, in line with the circular economy concept.

However, compared to woody biomass, agricultural residues have certain properties that make their thermochemical conversion less effective. In addition, their ash content is often 5- to 20 times higher. The ash-forming elements are generally dominated by silicon and potassium, the latter due to the use of fertilizers during crop cultivation. Such alkaline species, other alkaline earth metals, and problematic elements chlorine and sulfur may react with each other and/or with silica compounds through complex mechanisms to produce new chemicals and eutectics with low melting temperatures [7-10]. These compounds can cause ash slagging, fouling, and corrosion of heat exchange surfaces, thereby reducing the efficiency and availability of combustion systems and increasing the power cost [10-15].

To alleviate ash-related operational problems during the combustion of agricultural fuels, several approaches have been used: a) biomass leaching to remove soluble alkaline compounds, b) blending biomass with coal in existing infrastructures that offer simultaneously economic, environmental, and technical (lower ash deposition than stand-alone biomass systems) benefits and c) use of additives principally based on aluminosilicates $[3,8,14]$.

Additives can capture problematic ash species by physical or chemical adsorption, or increase ash melting temperatures by altering the ash chemistry during combustion $[7,11,16,17]$. Kaolin has been proven highly effective in improving the slagging behavior of biomass fuels, such as straws $[4,7,18]$, wood pellets [3, 9], and olive cake [9], by decreasing the initial deformation temperature of ashes between 200 and $240{ }^{\circ} \mathrm{C}$. Similarly, Ca-based additives and coal fly ash have been found to mitigate the melting of straws [4, 9, 16], herbaceous biomass [6], wood, and olive cake $[9,16]$ by lowering the initial deformation temperature of ashes between 40 - and $140{ }^{\circ} \mathrm{C}$ and 55 - and $90{ }^{\circ} \mathrm{C}$, respectively.

Although several studies have determined the characteristic fusion temperatures of biomass ashes and predicted their slagging potential in boilers while using aluminosilicate additives, there is a lack of data on the efficacy of bauxite and clinochlore minerals, mined in large quantities in several countries, when added to different biomass types, such as agricultural wastes and perennial non-food crops. Furthermore, the ash melting behavior of ashes produced by blending biomass materials with lignite and mixing with additives has not yet been studied. Previous investigations focused on high-rank coals $[10,15]$. However, the properties of ashes formed during the combustion of a fuel mix cannot be predicted from those of parent fuels. In addition, mutual interactions can occur that may or may not be beneficial. Therefore, knowledge of the behavior of the final ash materials on system performance is important to avoid fuel combinations with unwanted properties. 
Based on the above discussion, we studied the ash fusibility behavior of selected agricultural residues and their blends with lignite by performing chemical, mineralogical, fusibility, and thermogravimetric analyses and assessing the slagging/fouling propensities. Two additives, namely bauxite and clinochlore, were used at varying amounts to mitigate ash melting and so the deposition phenomenon in the combustion units. In addition, their anti-fusion mechanisms were explored in detail. Given that the exploitation of waste materials for power production is limited in most countries, current results are expected to offer valuable information to promote these wastes in fueling combustion enterprises. Moreover, the study of the effect of chemistry and mineralogy of inorganic constituents of coal/biomass blends on the fusibility behavior of ashes and determining slagging/fouling phenomena in boilers will provide additional data for the successful operation of fixed-bed biomass fired appliances, such as grate furnaces or underfeed stokers, and coal/biomass co-firing units, such as stokers.

\section{Experimental}

\subsection{Raw Materials}

The raw materials of this work were one lignite from Western Macedonia mines in North Greece $(\mathrm{ML})$ and three biomass materials abundantly found in the fields near the area, namely cardoon (Cynara Cardunculus L, CY), straw of hard wheat (SW), and peach kernels (PEK) provided by a local juice factory. After homogenization and riffling, all samples were ground and sieved to a particle size $\leq 200 \mu \mathrm{m}$ (lignite in a jaw crusher and ball mill, biomasses in a cutting mill). Each biomass material was mixed with the lignite at a ratio of 30:70, which is typical for co-firing applications in Europe [19]. Representative samples of fuels were characterized in terms of proximate analysis, ultimate analysis, and calorific value, following the ASTM standards (D5142, D5373, D5865) and European CEN/TC335 standards for the lignite and biomasses, respectively.

The additives-bauxite and clinochlore-were selected to reduce the slagging and fouling tendency of ashes during combustion. These are rich in Al and Si, respectively. These were mixed at $3 \%$ and $5 \%$ mass fraction to each biomass fuel, corresponding to additive/ash ratios of 0.19 $0.32: 1,0.26-0.43: 1,0.58-0.98: 1$, for cardoon, straw, and peach kernels, respectively. In the case of lignite/biomass mixtures, additive/ash ratios were 0.13-0.22:1, 0.14-0.23:1, 0.15-0.25:1, for $\mathrm{ML} / \mathrm{CY}, \mathrm{ML} / \mathrm{SW}$ and $\mathrm{ML} / \mathrm{PEK}$, respectively. Both additives were characterized by $\mathrm{X}$-ray diffractometry (XRD).

\subsection{Analysis of Fuel Ashes and Additive Blends}

Raw materials, lignite/biomass mixtures, and their blends with additives were ashed into a muffle furnace at $550{ }^{\circ} \mathrm{C}$ and $1200{ }^{\circ} \mathrm{C}$ to study the changes in the composition and thermal behavior. The decomposition of additives was assessed by thermogravimetric analysis TG/DTG (accuracy $0.2 \% \mathrm{wt}$, sensitivity $<5 \mu \mathrm{g}$, temperature precision $\pm 2{ }^{\circ} \mathrm{C}$ ). The weight loss (TG curves) and the rate of weight loss (DTG curves) were recorded continuously under nitrogen of flow rate of 35 $\mathrm{mL} / \mathrm{min}$, up to $1000^{\circ} \mathrm{C}$ with a heating rate of $10^{\circ} \mathrm{C} / \mathrm{min}$.

Fusibility test was conducted according to the European standard DDCEN/TS 15370-1:2006 using a heating microscope equipped with a high definition video camera, model Leitz Wetzlar EM201 of Hesse Instruments. Ash specimens (produced at $550{ }^{\circ} \mathrm{C}$ ) were heated up to $1550{ }^{\circ} \mathrm{C}$ at a 
rate of $5{ }^{\circ} \mathrm{C} / \mathrm{min}$ in an oxidizing atmosphere. The characteristic fusion temperatures, i.e., the initial deformation IDT, softening ST, hemispherical HT, and fluid FT temperatures were recorded during the test.

The crystalline phases of the ashes were detected using an X-ray diffractometer (XRD), type D8 Advance of Bruker AXS. The scanning range was 2- to $702 \theta^{\circ}$, with increments of $0.02^{\circ} / \mathrm{s}$. Minerals were identified using the software DIFFRAC plus Evaluation in conjunction with the JCPDS database.

Chemical analysis of the major inorganic elements of ashes was performed using an X-ray fluorescence spectrometer, model S2 Ranger/EDS of Bruker AXS.

\subsection{Slagging and Fouling Indices}

The slagging and fouling indices adopted in the present study are widely accepted, in conjunction with a pilot plant testing, to predict the deposition tendency of ashes in boilers and were based on the chemical composition of ashes, according to the standards previously discussed.

For biomass fuels, the alkali index (Al) expresses the amount of alkali oxides in the fuel per unit energy in GJ [20]:

$$
\mathrm{Al}=\operatorname{kg}\left(\mathrm{K}_{2} \mathrm{O}+\mathrm{Na}_{2} \mathrm{O}\right) / \mathrm{GJ}
$$

when $\mathrm{Al}=0.17-0.34 \mathrm{~kg} / \mathrm{GJ}$, the deposition tendency is low, whereas when $\mathrm{Al}>0.34 \mathrm{~kg} / \mathrm{GJ}$ the deposition tendency is high.

The base-to-acid ratio $(B / A)$ is given by [20]:

$$
\mathrm{B} / \mathrm{A}=\%\left(\mathrm{Fe}_{2} \mathrm{O}_{2}+\mathrm{CaO}+\mathrm{MgO}+\mathrm{K}_{2} \mathrm{O}+\mathrm{Na}_{2} \mathrm{O}\right) /\left(\mathrm{Si}_{2} \mathrm{O}+\mathrm{TiO}_{2}+\mathrm{Al}_{2} \mathrm{O}_{3}\right)
$$

when $B / A<0.5$, the deposition tendency is low; when $0.5<B / A<1$, the deposition tendency is medium; when $B / A>1$, the deposition tendency is high.

The fouling index (Fu) and Babcock index (Rs) are based on the B/A ratio and are expressed as [12]:

$$
\begin{gathered}
\mathrm{Fu}=(\mathrm{B} / \mathrm{A})\left(\mathrm{K}_{2} \mathrm{O}+\mathrm{Na}_{2} \mathrm{O}\right) \\
\mathrm{Rs}=(\mathrm{B} / \mathrm{A}) \mathrm{S}
\end{gathered}
$$

where $S$ is the percentage of sulfur in the dry fuel.

When Fu<0.6 and $\mathrm{Rs}<0.6$, the deposition tendency is low; when $0.6<\mathrm{Fu}<40$ and $0.6<\mathrm{Rs}<2$. the deposition tendency is medium; when $\mathrm{Fu}>40$ and $\mathrm{Rs}>2$, the deposition tendency is high.

The slag viscosity index (Sv) is calculated as follows [12]:

$$
\mathrm{Sv}=\mathrm{SiO}_{2} \cdot 100\left(\mathrm{Si}_{2} \mathrm{O}+\mathrm{Fe}_{2} \mathrm{O}_{2}+\mathrm{CaO}+\mathrm{MgO}\right)
$$

If Sv $>72$, the slagging tendency is low; if $65<\mathrm{Sv}<72$, the slagging tendency is medium; and if $\mathrm{Sv}<65$, the slagging tendency is high.

Finally, the ash fusibility index (Fs) is defined by [12]: 


$$
\mathrm{Fs}=(4 \mathrm{IDT}+\mathrm{HT}) / 5
$$

Fusibility is low when Fs $>1342$, medium when $1232<\mathrm{Fs}<1342$, and high when Fs $<1232$.

\section{Results and Discussion}

\subsection{Characterization of Raw Materials}

The proximate analysis of raw fuels, shown in Table 1, reveals that the volatile percentage of biomass fuels was considerably higher than that of lignite, ranging between 71 and $81 \%$, whereas the ash content was lower (5 to $15 \%$ ). According to the ultimate analysis, the higher oxygen content of biomass materials, compared to lignite, in conjunction with their lower carbon content, resulted in a lower calorific value, which nevertheless was significant and comparable to that of lignite. The concentration of nitrogen in cardoon was significantly high, implying undesirable $\mathrm{NO}_{\mathrm{x}}$ emissions during combustion. However, the sulfur content of all samples was low to negligible, suggesting insignificant $\mathrm{SO}_{\mathrm{x}}$ emissions during combustion.

The XRD spectra of the two additives used are represented in Figure 1. Bauxite consisted largely of diaspore, corundum, and hematite, and small amounts of kaolinite, gibbsite, and anatase. Clinochlore contained traces of quartz and ferrogedrite. Thermograms in Figure 2 show that the peak of bauxite at $535{ }^{\circ} \mathrm{C}$ corresponds to the decomposition of diaspore [21], whereas smaller peaks of clinochlore at $649{ }^{\circ} \mathrm{C}$ and $800{ }^{\circ} \mathrm{C}$ represent the evolution of water as steam [22]. The decomposition of clinochlore occurs above $840^{\circ} \mathrm{C}$.

Table 1 Proximate and ultimate analyses and calorific value of the fuels (\% dry weight).

\begin{tabular}{|c|c|c|c|c|c|c|c|c|c|}
\hline Sample & $\begin{array}{l}\text { Volatile } \\
\text { matter }\end{array}$ & $\begin{array}{l}\text { Fixed } \\
\text { Carbo } \\
\text { n }\end{array}$ & Ash & C & $\mathrm{H}$ & $\mathrm{N}$ & $\mathrm{O}$ & $S$ & $\begin{array}{l}\mathrm{GCV}^{\mathrm{a}} \\
(\mathrm{MJ} / \mathrm{kg})\end{array}$ \\
\hline \multicolumn{10}{|l|}{ Cynara } \\
\hline $\begin{array}{l}\text { Cardunculus L } \\
\text { (CY) }\end{array}$ & 71.5 & 13.2 & 15.3 & 41.4 & 6.0 & 2.8 & 33.9 & 0.2 & 19.2 \\
\hline $\begin{array}{l}\text { Straw of hard } \\
\text { wheat (SW) }\end{array}$ & 80.9 & 7.5 & 11.6 & 46.8 & 7.0 & 1.0 & 33.7 & - & 23.2 \\
\hline $\begin{array}{l}\text { Peach kernels } \\
\text { (PEK) }\end{array}$ & 76.0 & 18.7 & 5.3 & 49.5 & 6.1 & 1.2 & 38.1 & - & 20.0 \\
\hline $\begin{array}{l}\text { Macedonia } \\
\text { lignite (ML) }\end{array}$ & 57.5 & 17.1 & 25.4 & 49.9 & 5.5 & 1.6 & 26.6 & 0.5 & 25.7 \\
\hline
\end{tabular}

a Gross calorific value 

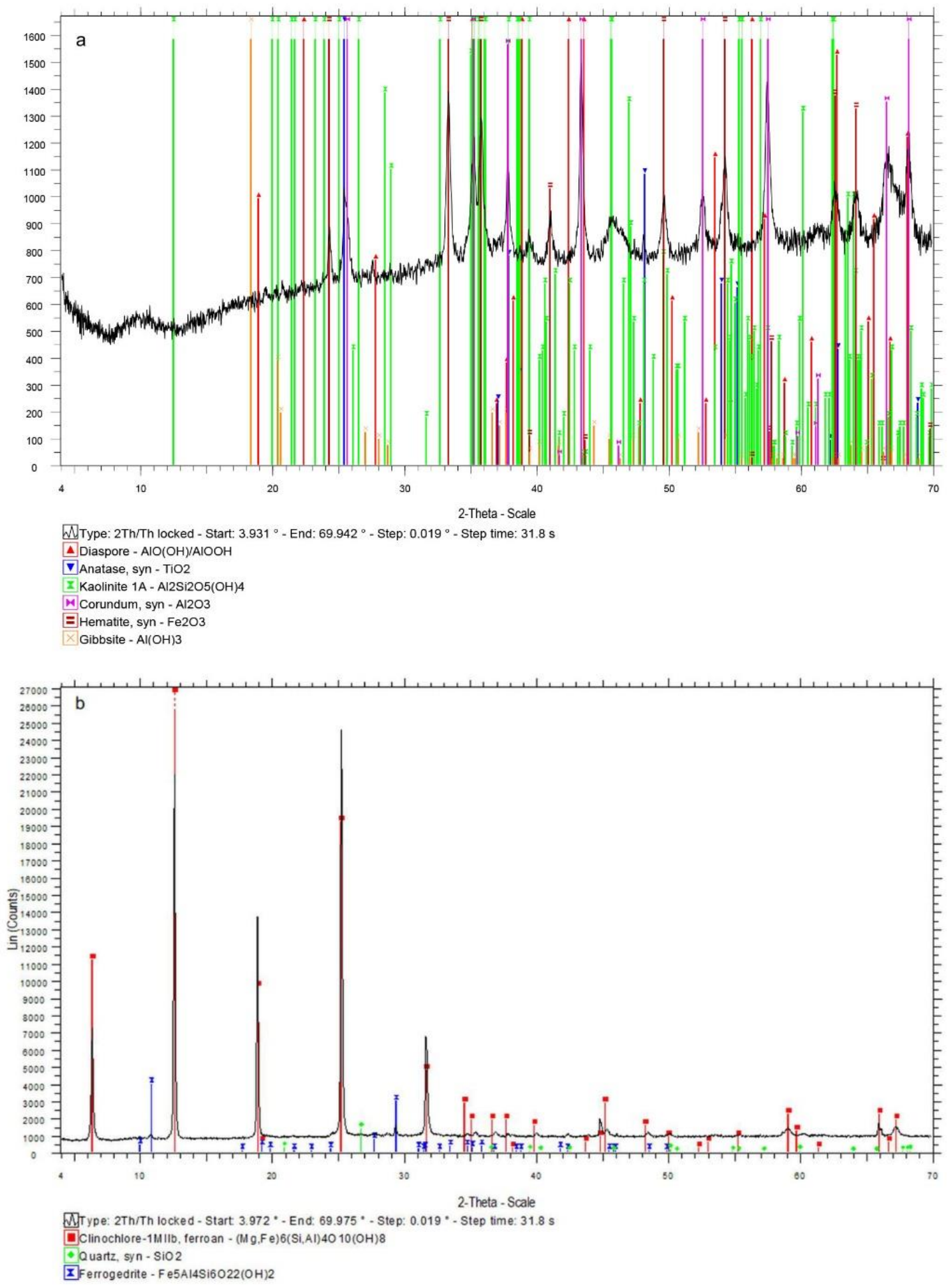

Figure 1 XRD spectra of (a) bauxite and (b) clinochlore additives. 


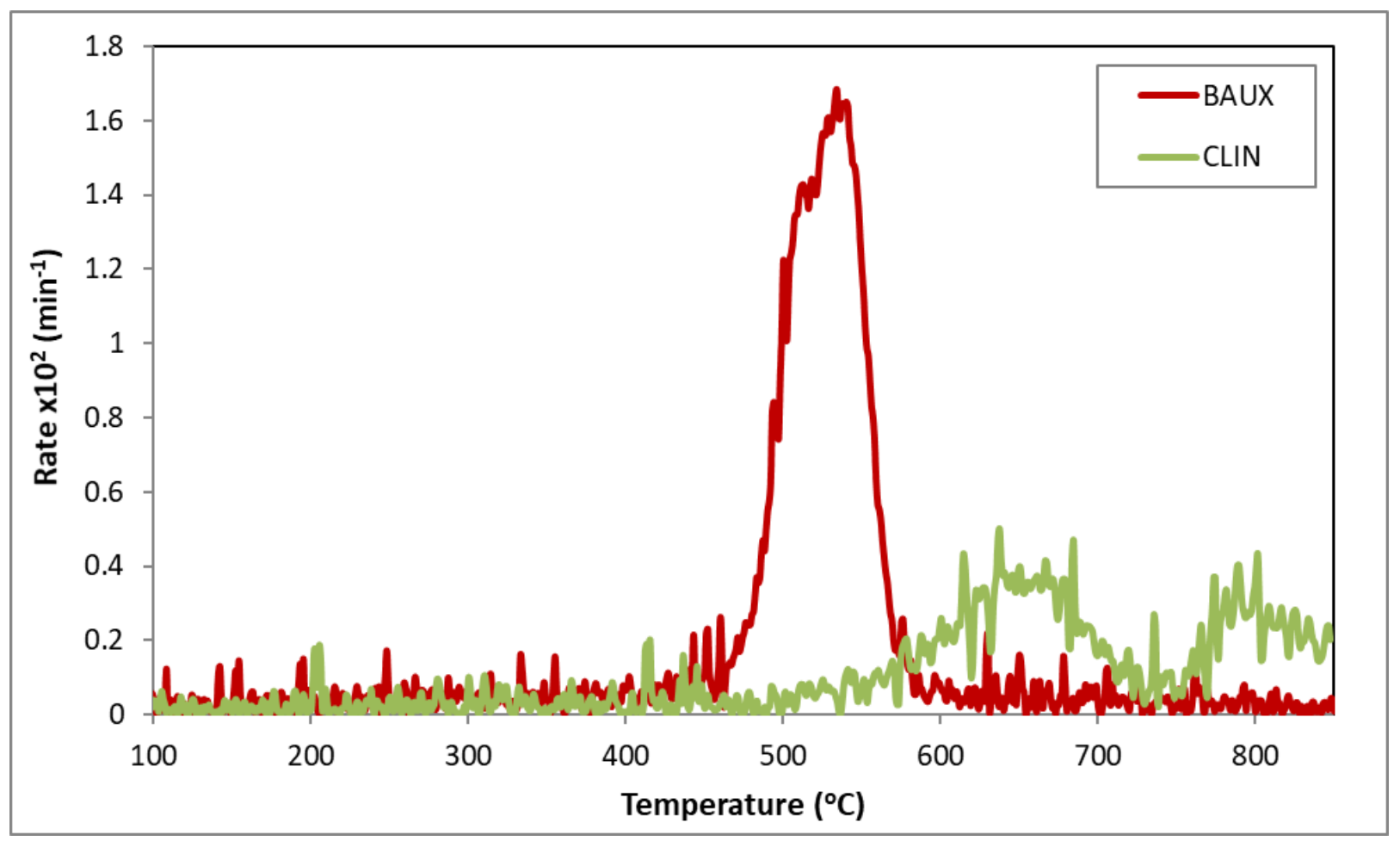

Figure 2 Thermograms of bauxite and clinochlore additives.

\subsection{Characterization of Fuel Ashes and Additive Blends}

\subsubsection{Melting Behavior}

The melting behavior of ashes was evaluated by the fusibility test. The characteristic fusion temperatures of biomass materials, with or without additives, as recorded by the heating microscope, are compared in Table 2 and Figure 3. The low IDT of all samples, varying between $867^{\circ} \mathrm{C}$ and $1010^{\circ} \mathrm{C}$, implies slagging and fouling effects in the boilers, apart from those operating below $900{ }^{\circ} \mathrm{C}$, such as fluid beds. The FT of PEK was particularly high $\left(1500^{\circ} \mathrm{C}\right)$, inferring that hightemperature molten materials were present or formed in this ash during heating. In contrast, $\mathrm{CY}$ presented not only the lowest FT but also the smallest difference between IDT and FT temperatures. This is known [15] to induce a higher fouling rate inside the combustion units, which was found to increase in the following order among the fuels tested: $C Y>S W>P E K$. 
Table 2 Fusibility analysis of biomass ashes with or without additives.

\begin{tabular}{lllll}
\hline Sample & $\begin{array}{l}\text { Initial } \\
\text { deformation } \\
\text { temperature } \\
(\text { IDT })\end{array}$ & $\begin{array}{l}\text { Softening } \\
\text { temperature }(\mathrm{ST}) \\
\left({ }^{\circ} \mathrm{C}\right)\end{array}$ & $\begin{array}{l}\text { Hemispherical } \\
\text { temperature }(\mathrm{HT}) \\
\left({ }^{\circ} \mathrm{C}\right)\end{array}$ & $\begin{array}{l}\text { Fluid } \\
\text { temperature }(\mathrm{FT}) \\
\left({ }^{\circ} \mathrm{C}\right)\end{array}$ \\
\hline $\mathrm{CY}$ & 867 & 1120 & 1178 & \\
$\mathrm{CY}+3 \%$ baux & 1209 & 1313 & 1382 & 1190 \\
$\mathrm{CY}+5 \%$ baux & 1205 & 1414 & 1443 & 1435 \\
$\mathrm{CY}+3 \%$ clin & 1162 & 1278 & 1297 & $>1550$ \\
$\mathrm{CY}+5 \%$ clin & 1177 & 1366 & 1450 & 1321 \\
$\mathrm{SW}$ & 1010 & 1085 & 1146 & $>1550$ \\
$\mathrm{SW}+3 \%$ baux & 1209 & 1362 & 1375 & 1242 \\
$\mathrm{SW}+5 \%$ baux & 1299 & 1509 & $>1550$ & 1515 \\
$\mathrm{SW}+3 \%$ clin & 1146 & 1308 & 1312 & $>1550$ \\
$\mathrm{SW}+5 \%$ clin & 1199 & 1358 & 1372 & 1404 \\
$\mathrm{PEK}$ & 917 & 1253 & 1421 & 1421 \\
$\mathrm{PEK}+3 \%$ baux & 1225 & 1355 & 1445 & 1500 \\
$\mathrm{PEK}+5 \%$ baux & 1254 & 1363 & 1465 & 1532 \\
$\mathrm{PEK}+3 \%$ clin & 1223 & 1338 & 1361 & 1420 \\
$\mathrm{PEK}+5 \%$ clin & 1250 & 1359 & 1392 & 1470 \\
\hline
\end{tabular}

CY: Cynara Cardunculus L, SW: Straw of hard wheat, PEK: Peach kernels 


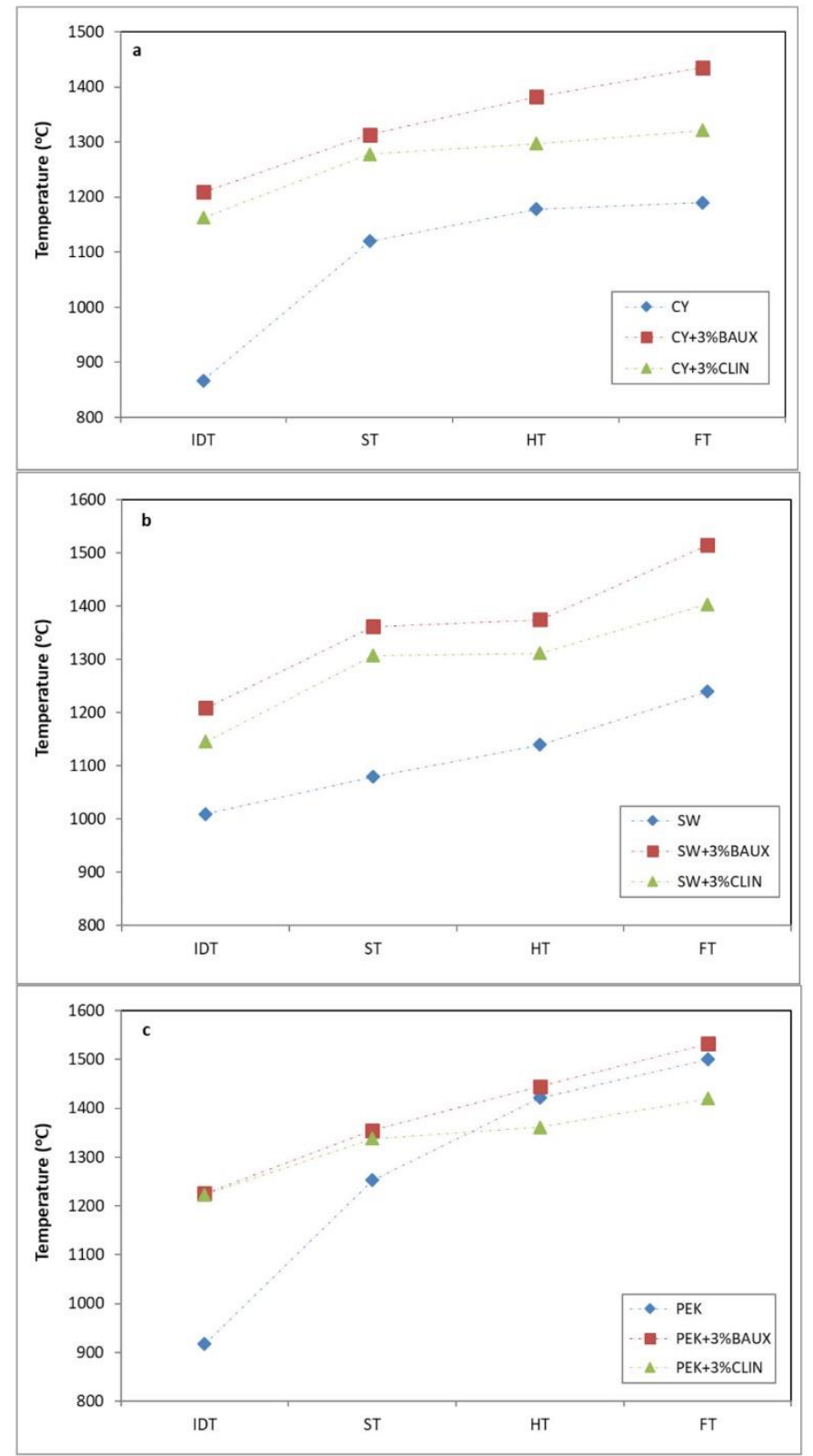

Figure 3 Characteristic fusion temperatures of (a) CY, (b) SW, and (c) PEK ashes with or without additives.

Furthermore, these results demonstrated that when bauxite or clinochlore, which consisted of high melting point (MP) minerals of $\mathrm{Si}, \mathrm{Al}, \mathrm{Fe}$, and $\mathrm{Mg}$, were added to biomass materials at percentages of $3 \%$ and $5 \% \mathrm{wt}$, all characteristic fusion temperatures were significantly increased. IDT of ashes commenced at temperatures 140 - to $340{ }^{\circ} \mathrm{C}$ higher, whereas $\mathrm{FT}$ in most cases exceeded $1500{ }^{\circ} \mathrm{C}$. As compared to the available literature, both bauxite and clinochlore are superior additives than kaolin or calcium oxide, which were found to lower the IDT of straws, wood and olive cake by $200-240{ }^{\circ} \mathrm{C}$ and $40-140{ }^{\circ} \mathrm{C}$, respectively $[4,6,9]$. In the case of mixtures with $3 \%$ additive, fusion temperatures were increased as follows: $P E K>S W>C Y$, whereas the expected fouling rate followed the reverse order, as in the case of raw fuels. Clinochlore was shown to be less effective in preventing the melting of ashes than bauxite. Moreover, from Table 
2 , it can be noticed that the higher amount of additive did not affect the melting data. Thus, a proportion of $3 \%$ of raw fuel was satisfactory for most combustion processes.

Regarding the blends of lignite with each biomass material, Table 3 shows that characteristic fusion temperatures were intermediate to each blend component and higher in comparison to each biomass fuel, except for HT and FT of PEK. The lower melting temperatures were recorded when $\mathrm{CY}$ was mixed with the lignite. However, the fouling rate of the blends was lower than that of lignite. The addition of either bauxite or clinochlore to fuel mixtures produced an enhancing effect on the fusion temperature values, as for raw fuels. The increase in IDT temperatures was between $190{ }^{\circ} \mathrm{C}$ and $250{ }^{\circ} \mathrm{C}$, whereas it was lower between $30{ }^{\circ} \mathrm{C}$ and $180{ }^{\circ} \mathrm{C}$ for $\mathrm{FT}$. Bauxite performed better than clinochlore, especially for the ML/SW mixture (Figure 4). Thus, the fusion temperature of blends increased in the order: $\mathrm{ML} / \mathrm{SW}+$ baux $>\mathrm{ML} / \mathrm{CY}+$ baux $>\mathrm{ML} / \mathrm{PEK}+$ baux.

Table 3 Fusibility analysis of lignite/biomass ashes with or without additives.

\begin{tabular}{|c|c|c|c|c|}
\hline Sample & $\begin{array}{l}\text { Initial } \\
\text { deformation } \\
\text { temperature } \\
(\text { IDT) } \\
\left({ }^{\circ} \mathrm{C}\right)\end{array}$ & $\begin{array}{l}\text { Softening } \\
\text { temperature (ST) } \\
\left({ }^{\circ} \mathrm{C}\right)\end{array}$ & $\begin{array}{l}\text { Hemispherical } \\
\text { temperature }(\mathrm{HT}) \\
\left({ }^{\circ} \mathrm{C}\right)\end{array}$ & $\begin{array}{l}\text { Fluid } \\
\text { temperature (FT) } \\
\left({ }^{\circ} \mathrm{C}\right)\end{array}$ \\
\hline$M L$ & 1120 & 1220 & 1335 & 1360 \\
\hline $\mathrm{ML} / \mathrm{CY}$ & 1059 & 1200 & 1295 & 1315 \\
\hline $\mathrm{ML} / \mathrm{CY}+3 \%$ baux & 1269 & 1290 & 1343 & 1350 \\
\hline $\mathrm{ML} / \mathrm{CY}+5 \%$ baux & 1267 & 1380 & 1398 & 1423 \\
\hline $\mathrm{ML} / \mathrm{CY}+3 \%$ clin & 1238 & 1249 & 1310 & 1332 \\
\hline $\mathrm{ML} / \mathrm{CY}+5 \%$ clin & 1251 & 1326 & 1334 & 1345 \\
\hline $\mathrm{ML} / \mathrm{SW}$ & 1015 & 1200 & 1290 & 1368 \\
\hline $\mathrm{ML} / \mathrm{SW}+3 \%$ baux & 1187 & 1360 & 1397 & 1508 \\
\hline $\mathrm{ML} / \mathrm{SW}+5 \%$ baux & 1265 & 1492 & 1550 & 1550 \\
\hline $\mathrm{ML} / \mathrm{SW}+3 \%$ clin & 1180 & 1275 & 1293 & 1392 \\
\hline $\mathrm{ML} / \mathrm{SW}+5 \%$ clin & 1240 & 1328 & 1333 & 1410 \\
\hline ML/PEK & 1069 & 1200 & 1362 & 1400 \\
\hline ML/PEK+3\% baux & 1253 & 1440 & 1448 & 1490 \\
\hline $\mathrm{ML} / \mathrm{PEK}+5 \%$ baux & 1276 & 1452 & 1460 & 1499 \\
\hline $\mathrm{ML} / \mathrm{PEK}+3 \%$ clin & 1230 & 1319 & 1332 & 1354 \\
\hline ML/PEK+5\% clin & 1254 & 1323 & 1332 & 1360 \\
\hline
\end{tabular}

CY: Cynara Cardunculus L, SW: Straw of hard wheat, PEK: Peach kernels, ML: Macedonia lignite 


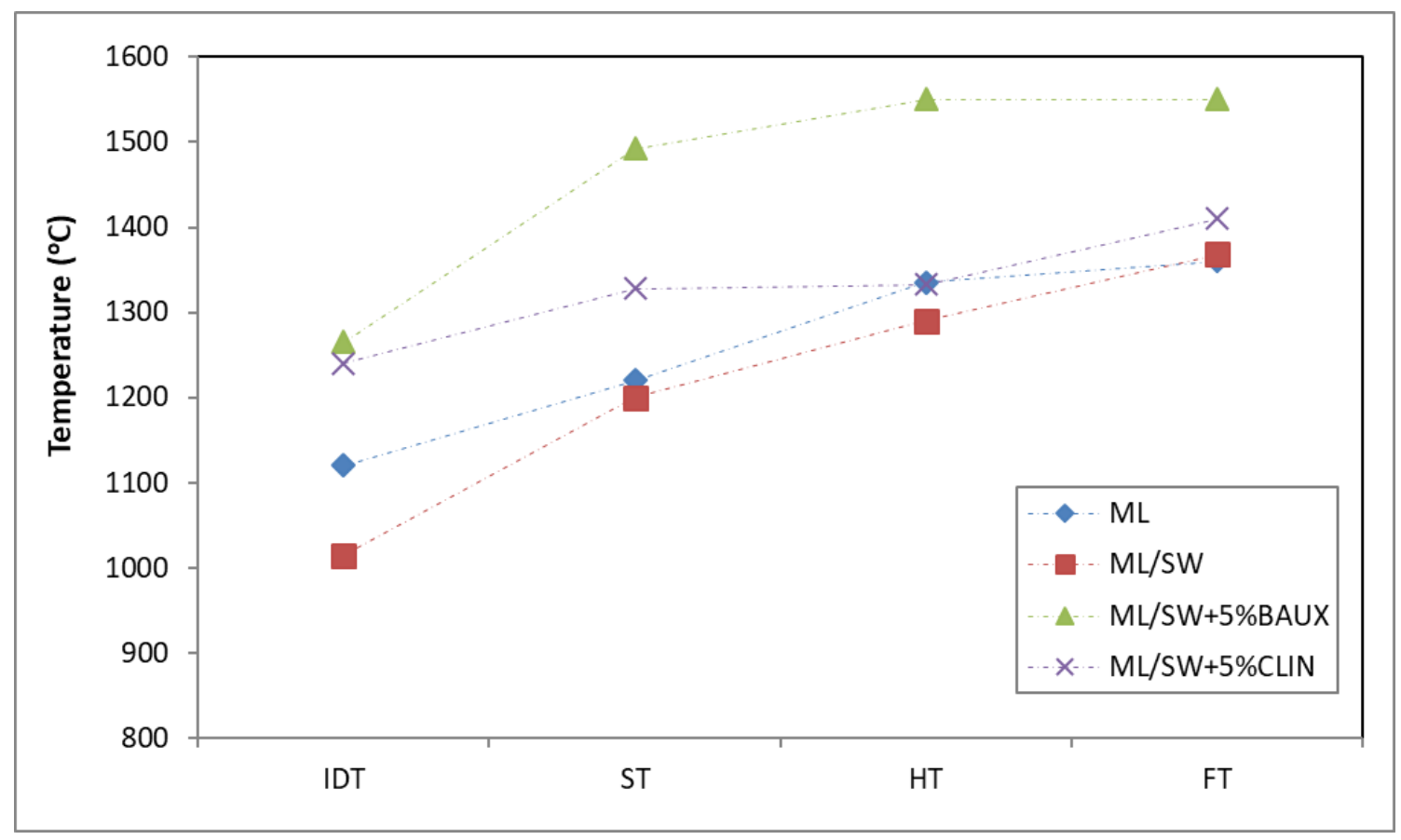

Figure 4 Characteristic ash fusion temperatures of ML/SW mixture with or without additives.

\subsubsection{Influence of Chemical Composition on Melting Behavior of Ashes}

No Additives Present. The results of XRF analysis of fuel ashes are represented in Figure 5a. The biomass ashes produced at $550{ }^{\circ} \mathrm{C}$ contained significantly higher concentrations of $\mathrm{K}, \mathrm{Na}$, and $\mathrm{P}$ with respect to lignite, whereas comparable to increased concentration of $\mathrm{Mg}$. The ash of lignite was richer in $\mathrm{Si}, \mathrm{Al}, \mathrm{Fe}$, and $\mathrm{Ca}$. An exception was the $\mathrm{Si}$ of straw, the total content of which reached $53 \% w t$ in the ash. With an increase in the ashing temperature to $1200{ }^{\circ} \mathrm{C}$, Figure $5 \mathrm{~b}$ shows that the amounts of $\mathrm{K}, \mathrm{Na}$, and $\mathrm{P}$ were reduced by 82 - to $94 \%, 11-$ to $80 \%$, and $29-$ to $82 \%$, respectively, among biomass samples. This suggests that these elements were present as volatile compounds in the ashes. In contrast, the proportions of $\mathrm{Si}, \mathrm{Al}, \mathrm{Fe}, \mathrm{Mg}$, and $\mathrm{Ca}$ increased at a higher temperature, revealing the association of these elements with more stable or less volatile compounds. 

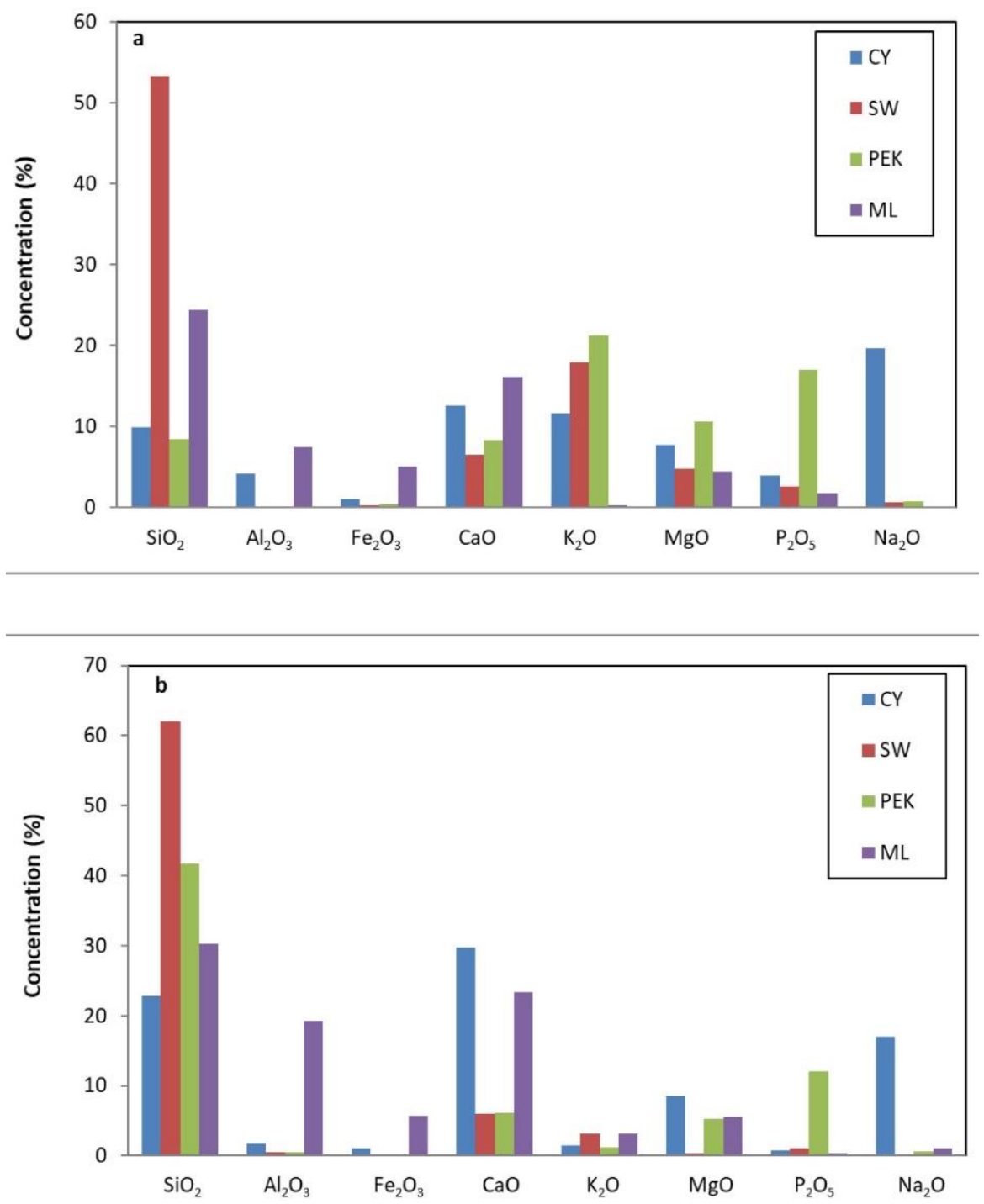

Figure 5 Chemical analysis of fuel ashes in major elements produced at (a) $550{ }^{\circ} \mathrm{C}$ and (b) $1200{ }^{\circ} \mathrm{C}$.

In Presence of Additives. When fuels were mixed with additives bauxite or clinochlore and ashed at $1200{ }^{\circ} \mathrm{C}$, according to the XRD results discussed below, the majority of new phases formed incorporated $\mathrm{K}$. Thus, the concentration of $\mathrm{K}$ in the ashes was compared to that determined with the addition of bauxite (Figure 6) for all biomass materials to investigate the $\mathrm{K}$ captured in the solid phase. The results showed that when the ashes were enriched with additive, the fraction of $\mathrm{K}$ retained in the ash was higher than in the raw fuels. The effect was less pronounced in peach kernel ash, implying that the additive decreased the volatility of $\mathrm{K}$ at high temperatures by promoting ash-fixing reactions between $\mathrm{K}$ and aluminosilicate minerals. The positive effect of kaolin additive on $\mathrm{K}$ capture ability was reported in previous studies [7, 23]. The chemical composition of lignite/biomass ash mixtures varied between that of component fuels. 


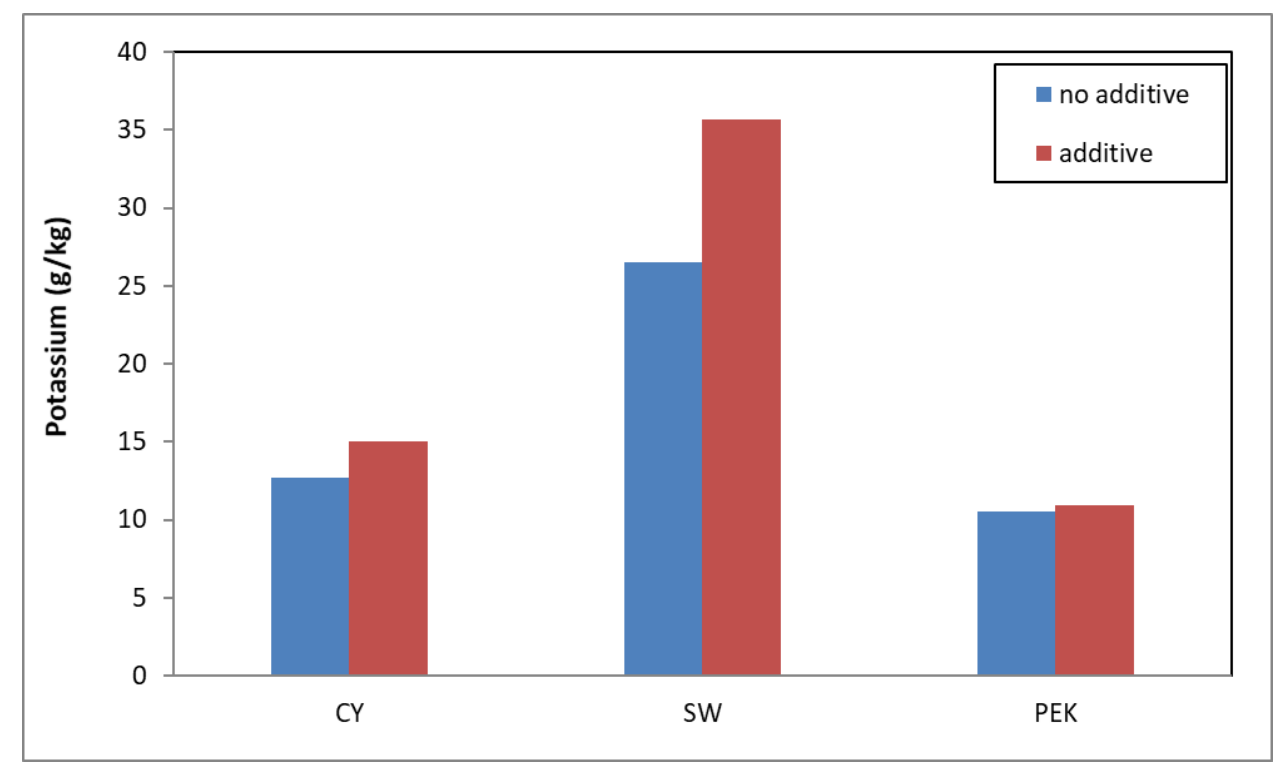

Figure 6 Concentration of potassium of fuel ashes produced at $1200{ }^{\circ} \mathrm{C}$, with or without bauxite additive ( $5 \%$ of biomass fuel).

The empirical slagging/fouling indices calculated based on the chemical composition of fuel ashes (equations 1 to 6 ) are compared in Table 4. These indices could be a useful tool in providing a quick pre-evaluation of deposition problems in boilers. In addition, these indicate that the fusion of ashes is a synthetic result of both acidic ( $\mathrm{Si}, \mathrm{Al}, \mathrm{Ti}$ ) and basic oxides ( $\mathrm{K}, \mathrm{Na}, \mathrm{Ca}, \mathrm{Mg}, \mathrm{Fe}$ ).

Table 4 Empirical slagging/fouling indices of fuels and blends.

\begin{tabular}{llllllll}
\hline Sample & Al & B/A & FU & RS & SV & FS & $\begin{array}{l}\text { Deposition } \\
\text { tendency }\end{array}$ \\
\hline CY & 2.55 & 3.73 & 116.37 & 0.74 & 31.83 & 929.2 & High \\
SW & 0.92 & 0.56 & 10.36 & - & 82.25 & 1036.0 & Medium to high \\
PEK & 0.56 & 4.80 & 105.12 & - & 30.39 & 1017.8 & High \\
ML & & 0.80 & 0.19 & 0.40 & 48.90 & 1163.0 & Medium \\
ML/CY 70:30 & & 0.94 & 3.57 & 0.38 & 43.57 & 1106.0 & Medium to high \\
ML/SW 70:30 & & 0.73 & 4.23 & - & 57.33 & 1070.0 & Medium to high \\
ML/PEK 70:30 & & 1.22 & 8.21 & - & 45.35 & 1128.0 & Medium to high \\
\hline
\end{tabular}

CY: Cynara Cardunculus L, SW: Straw of hard wheat, PEK: Peach kernels, ML: Macedonia lignite

With reference to the $\mathrm{Al}$ index, all biomass materials have certain fouling potential. The $\mathrm{B} / \mathrm{A}$ ratio confirmed the high deposition tendency of the fuels, except for straw, due to the dominance of basic oxides in ashes in relation to acidic ones. The high content of Si of straw was responsible for its medium fouling propensity, expressed by this index. Furthermore, Table 4 shows that the fouling index Fu was high for cardoon and peach kernels and medium for straw; however, it was low for lignite due to the low percentages of $\mathrm{K}$ and $\mathrm{Na}$ in the lignite ash. The Babcock index could not be applied to straw and peach kernel ashes as the content of sulfur in these was not measurable. According to this index, although cardoon had an extremely low concentration of sulfur, its slagging/fouling tendency is characterized as "medium: because of a high value of B/A 
ratio. In contrast, this tendency for lignite is characterized as "low," revealing that the significant amount of $\mathrm{SiO}_{2}$ in lignite ash could prevent the formation of deposits enriched in sulfur. The slag viscosity index Sv indicates that fuels with an elevated percentage of silica present a low ash deposition propensity was low only for straw and high for all other fuel ashes. Finally, regarding the fusibility index (Fs), the risk of ash melting in combustion boilers was considered high for all fuels studied, and ash-related problems should be expected in the following order: $\mathrm{CY}>\mathrm{PEK}>\mathrm{SW}>\mathrm{ML}$. For lignite/biomass blends, Table 4 shows that the deposition tendency remained unaltered with respect to lignite and was low-to-medium in relation to alkali and sulfur, whereas high in relation to slag viscosity and fusibility.

\subsubsection{Influence of Mineralogical Composition on Melting Behavior of Ashes}

No Additives Present. The melting behavior of ashes can be predicted by their mineralogical composition, as analyzed by XRD. During the heating of ashes at different temperatures, changes in the crystalline structure can occur, and mineral components might interact with each other causing variations in ash composition. The XRD analysis results of fuel ashes at ashing temperatures $550^{\circ} \mathrm{C}$ and $1200^{\circ} \mathrm{C}$ are shown in Table 5.

Table 5 Mineralogical analysis of fuel ashes at different temperatures.

\begin{tabular}{|c|c|c|c|c|c|c|c|c|}
\hline \multirow[t]{2}{*}{ Mineral phases } & \multicolumn{2}{|l|}{ ML } & \multicolumn{2}{|l|}{$\mathrm{CY}$} & \multicolumn{2}{|l|}{ SW } & \multicolumn{2}{|l|}{ PEK } \\
\hline & $550^{\circ} \mathrm{C}$ & $1200^{\circ} \mathrm{C}$ & $550^{\circ} \mathrm{C}$ & $1200^{\circ} \mathrm{C}$ & $550^{\circ} \mathrm{C}$ & $1200^{\circ} \mathrm{C}$ & $550^{\circ} \mathrm{C}$ & $1200^{\circ} \mathrm{C}$ \\
\hline Quartz $\mathrm{SiO}_{2}$ & +++ & +++ & ++ & & +++ & +++ & + & +++ \\
\hline Anhydrite $\mathrm{CaSO}_{4}$ & ++ & ++ & & & + & + & & \\
\hline Halite $\mathrm{NaCl}$ & & & ++ & & & & & \\
\hline Calcite $\mathrm{CaCO}_{3}$ & + & & ++ & + & + & & + & \\
\hline Microcline $\max \mathrm{K}\left(\mathrm{Si}_{3} \mathrm{Al}\right) \mathrm{O}_{8}$ & + & & & & & & + & + \\
\hline Fairchildite $\mathrm{K}_{2} \mathrm{Ca}\left(\mathrm{CO}_{3}\right)_{2}$ & & & & & + & + & & \\
\hline Archerite $\mathrm{K}\left(\mathrm{H}_{2} \mathrm{PO}_{4}\right)$ & & & & & & & + & \\
\hline Hydroxyapatite $\mathrm{Ca}_{5}\left(\mathrm{PO}_{4}\right)_{3}(\mathrm{OH})$ & & & & + & + & & ++ & + \\
\hline Fluorapatite $\mathrm{Ca}_{5}\left(\mathrm{PO}_{4}\right)_{3} \mathrm{~F}$ & & & + & & & & & \\
\hline Gehlenite $\mathrm{Ca}_{2} \mathrm{Al}(\mathrm{AlSi}) \mathrm{O}_{7}$ & & ++ & & & & + & & \\
\hline Hematite $\mathrm{Fe}_{2} \mathrm{O}_{3}$ & + & + & + & + & & & & \\
\hline Muscovite & + & + & & & & & & \\
\hline \multicolumn{9}{|l|}{$\mathrm{KAl}_{2}\left(\mathrm{Si}_{3} \mathrm{Al}\right) \mathrm{O}_{10}(\mathrm{OH}, \mathrm{F})_{2} / \mathrm{H}_{2} \mathrm{KAl}_{3} \mathrm{Si}_{3}$} \\
\hline \multicolumn{9}{|l|}{$\mathrm{O}_{12}$} \\
\hline Periclase MgO & + & + & + & + & & & & \\
\hline Albite calcian $(\mathrm{Na}, \mathrm{Ca})(\mathrm{Si}, \mathrm{Al})_{4} \mathrm{O}_{8}$ & + & & & & + & + & + & + \\
\hline Sylvite $\mathrm{KCl}$ & & & + & & ++ & & & \\
\hline Aphthitalite $\mathrm{K}_{3} \mathrm{Na}\left(\mathrm{SO}_{4}\right)_{2}$ & & & + & & & & & \\
\hline Krausite $\mathrm{KFe}\left(\mathrm{SO}_{4}\right)_{2} \mathrm{H}_{2} \mathrm{O}$ & & & + & & & & & \\
\hline Hatrurite $\mathrm{Ca}_{3}\left(\mathrm{SiO}_{4}\right) \mathrm{O}$ & & & & ++ & & & & \\
\hline Portlandite $\mathrm{Ca}(\mathrm{OH})_{2}$ & & & & + & & & & \\
\hline Nyererite $\mathrm{Na}_{2} \mathrm{Ca}\left(\mathrm{CO}_{3}\right)_{2}$ & & & + & & & & & \\
\hline
\end{tabular}


Whitlockite $\mathrm{Ca}_{3}\left(\mathrm{PO}_{4}\right)_{2}$

Mullite $3 \mathrm{Al}_{2} \mathrm{O}_{3} \cdot 2 \mathrm{SiO}_{2}$

Tridymite $\mathrm{SiO}_{2}$

Brownmillerite $\mathrm{Ca}_{2} \mathrm{FeAlO}_{5}$

Dolomite $\mathrm{CaMg}\left(\mathrm{CO}_{3}\right)_{2}$

Orthoclase $\mathrm{KAISi}_{3} \mathrm{O}_{8}$

sodian

$\mathrm{Ca}_{0.66} \mathrm{Na}_{0.34} \mathrm{Al}_{1.66} \mathrm{Si}_{2.34} \mathrm{O}_{8}$

Rokuhnite $\mathrm{FeCl}_{2} . \mathrm{H}_{2} \mathrm{O}$

Albite $\mathrm{NaAlSi}_{3} \mathrm{O}_{8}$

Niter $\mathrm{K}\left(\mathrm{NO}_{3}\right)$

Buetschliite $\mathrm{K}_{2} \mathrm{Ca}\left(\mathrm{CO}_{3}\right)_{2}$

Maghemite $\mathrm{Fe}_{2} \mathrm{O}_{3}$

Arcanite $\mathrm{K}_{2} \mathrm{SO}_{4}$

Lime $\mathrm{CaO}$

Diopside $\mathrm{Ca}(\mathrm{Mg}, \mathrm{Al})(\mathrm{Si}, \mathrm{Al})_{2} \mathrm{O}_{6}$

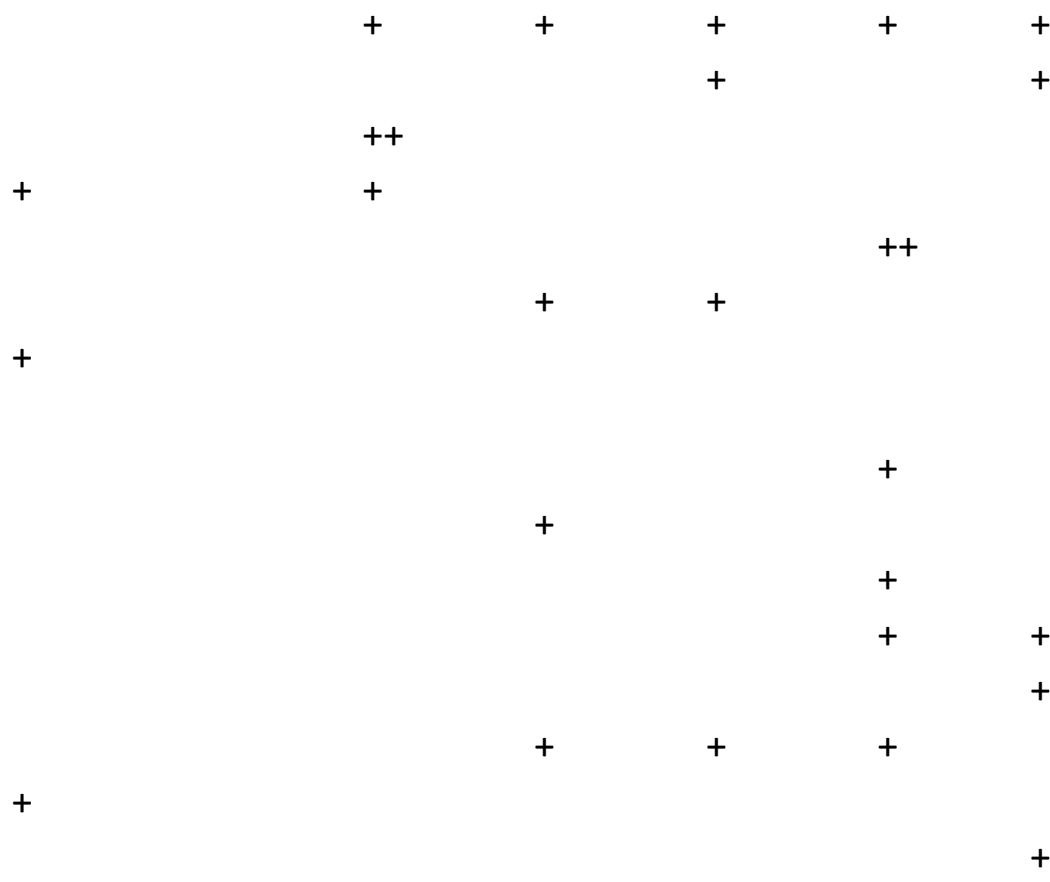

Larnite $\mathrm{Ca}_{2} \mathrm{SiO}_{4}$

$++$

+++: high intensity ++: medium intensity +: low intensity

CY: Cynara Cardunculus L, SW: Straw of hard wheat, PEK: Peach kernels, ML: Macedonia lignite

Cardoon ashed at $550{ }^{\circ} \mathrm{C}$ was dominated by chlorides, sulfates, and carbonates of $\mathrm{K}$ and $\mathrm{Na}$, in agreement with the chemical analysis. $\mathrm{Ca}$ and Si were present in moderate amounts as calcite and quartz, whereas the concentrations of $\mathrm{Mg}$ as periclase and $\mathrm{P}$ as fluorapatite were smaller. Therefore, the low IDT $867{ }^{\circ} \mathrm{C}$ and FT $1190^{\circ} \mathrm{C}$ of cardoon (Table 2) can be assigned to the fusible forms of sylvite (MP $\left.790{ }^{\circ} \mathrm{C}\right)$, halite $\left(\mathrm{MP} 801{ }^{\circ} \mathrm{C}\right)$, aphthitalite (MP $\left.900{ }^{\circ} \mathrm{C}\right)$, krausite (MP $\left.156.6^{\circ} \mathrm{C}\right)$, and nyererite (MP $815^{\circ} \mathrm{C}$ ) $[13,24-26]$. With an increase in the ashing temperature to $1200{ }^{\circ} \mathrm{C}$, as can be observed, chlorides, sulfates, and carbonates of $\mathrm{K}$ and $\mathrm{Na}$ were not identified as they were evaporated into the gas phase or decomposed. In addition, Table 5 implies that calcite was partially decomposed to lime, forming new phases with $\mathrm{SiO}_{2}$ (larnite, hatrurite) and $\mathrm{Fe}_{2} \mathrm{O}_{3}$ (brownmillerite) and absorbing moisture after ashing (portlandite).

For straw ash of $550^{\circ} \mathrm{C}$, Table 5 shows that silicon was incorporated in high amounts as quartz, which is consistent with the XRF analysis (Figure 5a) and in lower amounts in feldspars (albite, orthoclase). In addition, $\mathrm{K}$ was present in a high proportion as arcanite, sylvite, and fairchildite. $\mathrm{Ca}$ and $\mathrm{P}$ were detected in the forms of calcite, anhydrite, and hydroxyapatite, whitlockite, respectively. As for the cardoon ash, the fusible forms of arcanite (MP 1070), sylvite, and fairchildite (MP $815^{\circ} \mathrm{C}$ ) $[13,24-26]$ minerals were responsible for the relatively low IDT and ST $\left(1010-1080{ }^{\circ} \mathrm{C}\right)$ of this biomass material. Sylvite and hydroxyapatite were found to volatilize at a higher temperature of $1200{ }^{\circ} \mathrm{C}$, whereas calcite was decomposed to lime and transformed to gehlenite, most probably by reacting with an aluminosilicate. Moreover, Table 5 shows that mullite in the $1200^{\circ} \mathrm{C}$ ash was generated from albite.

The XRD pattern of peach kernels ash at $550{ }^{\circ} \mathrm{C}$ shows that this biomass ash consisted primarily of $\mathrm{K}$ and $\mathrm{P}$ crystalline phases, in accordance with its chemical analysis previously presented, which appeared in the form of arcanite, niter, buetschliite, and phosphates archerite, hydroxyapatite and whitlockite. $\mathrm{Mg}, \mathrm{Ca}$, and $\mathrm{Si}$ were also incorporated in considerable amounts in dolomite, 
calcite, quartz, and feldspars (albite, microcline). Iron was detected in a smaller quantity as rokuhnite. The low IDT of peach kernels $917^{\circ} \mathrm{C}$ (as shown in Table 2) was attributed to the low melting point minerals arcanite (MP $\left.1070{ }^{\circ} \mathrm{C}\right)$, niter (MP $\left.334^{\circ} \mathrm{C}\right)$, and buetschliite (MP $\left.815^{\circ} \mathrm{C}\right)[25$, 27]. Increasing the ashing temperature to $1200{ }^{\circ} \mathrm{C}$ led to the evaporation of sulfate, nitrate, and phosphate phases of $\mathrm{K}$. In addition, rokuhnite was oxidized to maghemite, and albite was partially converted to mullite. Furthermore, calcite and dolomite were decomposed at this temperature to lime and periclase, forming a new phase through a reaction with $\mathrm{SiO}_{2}$, diopside $\left(\mathrm{MP}>1300{ }^{\circ} \mathrm{C}\right)$ [24]. These mineralogical transformations during the heating of peach kernels ash to phases with high melting point (between $1300^{\circ} \mathrm{C}$ and $1910^{\circ} \mathrm{C}$ ), combined with the loss of fusible forms of $\mathrm{K}$, explain the high FT of this material $\left(1500^{\circ} \mathrm{C}\right)$.

The ash of lignite, which was found by XRF analysis to be consisting of higher proportions of Si, $\mathrm{Al}$, and $\mathrm{Ca}$ than those in biomass ashes, presented significant amounts of quartz, aluminosilicates, calcite, and anhydrite. The contributions of Fe and Mg were small, in the forms of hematite and periclase, respectively. Accordingly, the higher fusion temperatures of lignite than those of biomass fuels reflect its composition in minerals with a high melting point $\left(>1300{ }^{\circ} \mathrm{C}\right)$. When the ashing temperature was increased to $1200{ }^{\circ} \mathrm{C}$, Table 5 shows that calcite decomposed to lime, which reacted with quartz, hematite, and an aluminosilicate to form the new phases of larnite, brownmillerite, and gehlenite, respectively.

In Presence of Additives. The crystalline mineral phases identified in the XRD spectra, in the presence of additives, are listed in Table 6. As shown in Figure 2, diaspore in bauxite decomposed at $535{ }^{\circ} \mathrm{C}$ to corundum, explaining the absence of diaspore phase at $1200{ }^{\circ} \mathrm{C}$. Furthermore, clinochlore was decomposed above $840{ }^{\circ} \mathrm{C}$ to forsterite, spinel, enstatite, and fayalite. When bauxite was added to cardoon, several new phases were formed. Gehlenite (MP $1593{ }^{\circ} \mathrm{C}$ ) and merwinite (MP $1553{ }^{\circ} \mathrm{C}$ ) [26] were generated by lime and periclase of cardoon ash with the aluminosilicate additive as follows:

$$
\begin{aligned}
& 2 \mathrm{CaO}+\mathrm{SiO}_{2}+\mathrm{Al}_{2} \mathrm{O}_{3} \rightarrow \mathrm{Ca}_{2} \mathrm{Al}_{2} \mathrm{SiO}_{7} \\
& 3 \mathrm{CaO}+2 \mathrm{SiO}_{2}+\mathrm{MgO} \rightarrow \mathrm{Ca}_{3} \mathrm{MgSi}_{2} \mathrm{O}_{8}
\end{aligned}
$$

\begin{tabular}{|c|c|c|c|c|c|c|c|c|}
\hline \multirow[t]{2}{*}{ Mineral phases } & \multirow[b]{2}{*}{ Bauxite } & \multirow[b]{2}{*}{ Clinochlore } & \multicolumn{2}{|l|}{$\mathrm{CY}$} & \multicolumn{2}{|l|}{ SW } & \multicolumn{2}{|l|}{ PEK } \\
\hline & & & Bauxite & $\begin{array}{l}\text { Clinochl } \\
\text { ore }\end{array}$ & Bauxite & $\begin{array}{l}\text { Clinochl } \\
\text { ore }\end{array}$ & Bauxite & $\begin{array}{l}\text { Clinochl } \\
\text { ore }\end{array}$ \\
\hline Quartz $\mathrm{SiO}_{2}$ & & & & & ++ & ++ & +++ & \\
\hline Anhydrite $\mathrm{CaSO}_{4}$ & & & & & + & + & & \\
\hline Merwinite $\mathrm{Ca}_{3} \mathrm{Mg}\left(\mathrm{SiO}_{4}\right)_{2}$ & & & ++ & ++ & & & & \\
\hline Leucite $\mathrm{KaISi}_{2} \mathrm{O}_{6}$ & & & & + & ++ & + & + & \\
\hline Microcline $\max \mathrm{K}\left(\mathrm{Si}_{3} \mathrm{Al}\right) \mathrm{O}_{8}$ & & & ++ & & & & + & +++ \\
\hline Nepheline $\mathrm{Na}_{3} \mathrm{KAl}_{4} \mathrm{Si}_{4} \mathrm{O}_{16}$ & & & + & + & & & & \\
\hline Merrihueite $\mathrm{K}_{2} \mathrm{Mg}_{5} \mathrm{Si}_{12} \mathrm{O}_{30}$ & & & & + & & & & \\
\hline
\end{tabular}

Table 6 Mineralogical analysis of fuel ashes $\left(1200^{\circ} \mathrm{C}\right)$ in the presence of additives. 
Hydroxyapatite

$\mathrm{Ca}_{5}\left(\mathrm{PO}_{4}\right)_{3}(\mathrm{OH})$

Gehlenite $\mathrm{Ca}_{2} \mathrm{Al}(\mathrm{AlSi}) \mathrm{O}_{7}$

Hematite $\mathrm{Fe}_{2} \mathrm{O}_{3}$

$++$

Goethite $\mathrm{FeO}(\mathrm{OH})$

Periclase MgO

Albite

calcian

$(\mathrm{Na}, \mathrm{Ca})(\mathrm{Si}, \mathrm{Al})_{4} \mathrm{O}_{8}$

Monticellite $\mathrm{CaMgSiO}_{4}$

Forsterite

ferroan

$\mathrm{Mg}_{1.8} \mathrm{Fe}_{0.2}\left(\mathrm{SiO}_{4}\right)$

Enstatite aluminian

( $\left.\mathrm{Mg}_{0.9} \mathrm{Al}_{0.04}\right)\left(\mathrm{Al}_{0.04} \mathrm{Si}_{0.9} \mathrm{O}_{3}\right)$

Spinel

( $\left.\mathrm{Mg}_{0.64} \mathrm{Al}_{0.36}\right)\left(\mathrm{Al}_{0.82} \mathrm{Mg}_{0.18}\right)_{2} \mathrm{O}$

4

Gibbsite $\mathrm{Al}(\mathrm{OH})_{3}$

Hatrurite $\mathrm{Ca}_{3}\left(\mathrm{SiO}_{4}\right) \mathrm{O}$

Tridymite $\mathrm{SiO}_{2}$

Whitlockite $\mathrm{Ca}_{3}\left(\mathrm{PO}_{4}\right)_{2}$

Mullite $3 \mathrm{Al}_{2} \mathrm{O}_{3} .2 \mathrm{SiO}_{2}$

Brownmillerite $\mathrm{Ca}_{2} \mathrm{FeAlO}_{5}$

Kalsilite $\mathrm{KAl}\left(\mathrm{SiO}_{4}\right)$

Orthoclase $\mathrm{KAISi}_{3} \mathrm{O}_{8}$

Corundum $\mathrm{Al}_{2} \mathrm{O}_{3}$

Limenite $\mathrm{FeTiO}_{3}$

Albite $\mathrm{NaAlSi}_{3} \mathrm{O}_{8}$

Fayalite $\mathrm{Fe}_{2} 2 \mathrm{SiO}_{4}$

Buetschliite $\mathrm{K}_{2} \mathrm{Ca}\left(\mathrm{CO}_{3}\right)_{2}$

Maghemite $\mathrm{Fe}_{2} \mathrm{O}_{3}$

Anatase $\mathrm{TiO}_{2}$

Wollastonite $\mathrm{CaSiO}_{3}$

Diopside

$\mathrm{Ca}(\mathrm{Mg}, \mathrm{Al})(\mathrm{Si}, \mathrm{Al})_{2} \mathrm{O}_{6}$

Larnite $\mathrm{Ca}_{2} \mathrm{SiO}_{4}$

+++

$+$

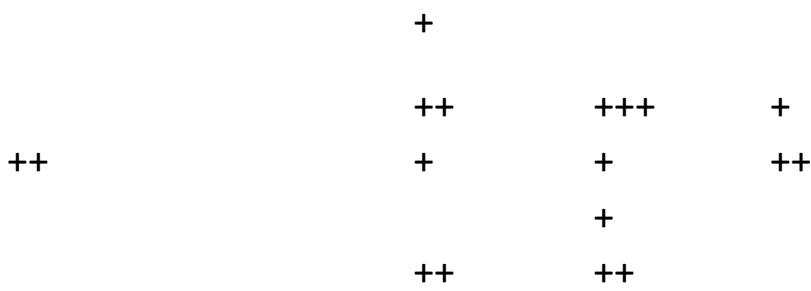

$+++$

$++$

$++$

$++$

$+++$

$++$

$++$

$+$

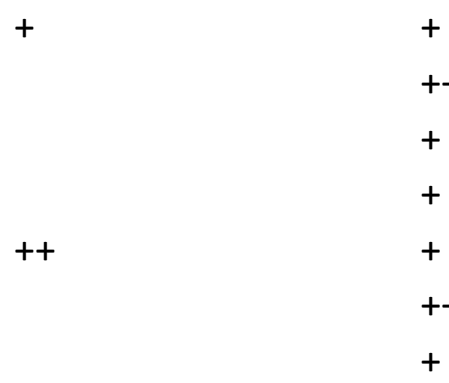

$+$

$+++$

$+$

$+$
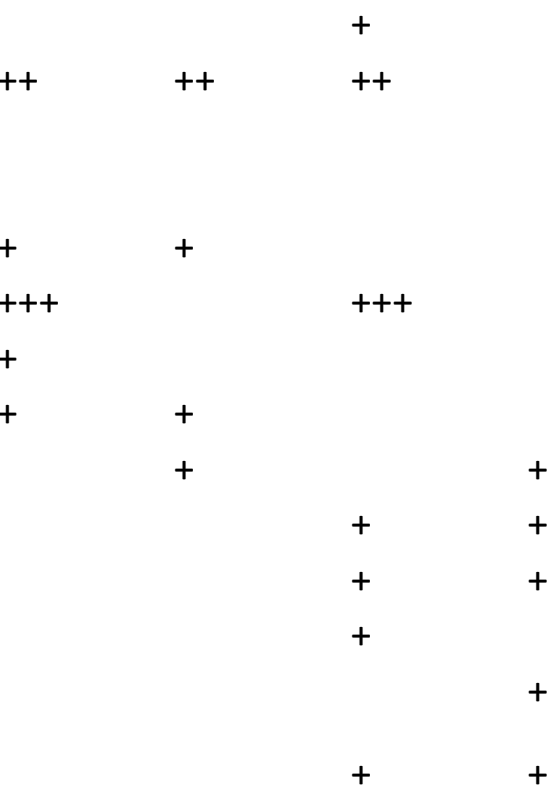

+++

$+++$

$++$

+++: high intensity ++: medium intensity + : low intensity

CY: Cynara Cardunculus L, SW: Straw of hard wheat, PEK: Peach kernels

Sylvite and arcanite, which were liberated during ashing at $1200{ }^{\circ} \mathrm{C}$, reacted with bauxite to produce microcline $\left(\mathrm{MP} 1150^{\circ} \mathrm{C}\right)$ :

$$
\begin{gathered}
2 \mathrm{KCl}+\mathrm{Al}_{2} \mathrm{O}_{3} \cdot \mathrm{SiO}_{2}+5 \mathrm{SiO}_{2}+\mathrm{H}_{2} \mathrm{O} \rightarrow 2 \mathrm{KAlSi}_{3} \mathrm{O}_{8}+2 \mathrm{HCl} \\
\mathrm{K}_{2} \mathrm{SO}_{4}+\mathrm{Al}_{2} \mathrm{O}_{3} \cdot \mathrm{SiO}_{2}+5 \mathrm{SiO}_{2} \rightarrow 2 \mathrm{KAISi}_{3} \mathrm{O}_{8}+\mathrm{SO}_{3}
\end{gathered}
$$


Furthermore, bauxite promoted the reactions with $\mathrm{K}$-and $\mathrm{Na}$-bearing minerals of cardoon evaporated at $1200{ }^{\circ} \mathrm{C}$ (as shown above) to form new phases kalsilite (MP $1500{ }^{\circ} \mathrm{C}$ ) [4] and nepheline (MP $\left.1550^{\circ} \mathrm{C}\right)[28]$ :

$$
\begin{gathered}
2 \mathrm{KCl}+2 \mathrm{SiO}_{2}+\mathrm{Al}_{2} \mathrm{O}_{3}+\mathrm{H}_{2} \mathrm{O} \rightarrow 2 \mathrm{KAlSiO}_{4}+2 \mathrm{HCl} \\
\mathrm{K}_{2} \mathrm{SO}_{4}+2 \mathrm{SiO}_{2}+\mathrm{Al}_{2} \mathrm{O}_{3} \rightarrow 2 \mathrm{KAlSiO}_{4}+\mathrm{SO}_{3} \\
3 \mathrm{NaCl}+\mathrm{KCl}+4 \mathrm{SiO}_{2}+2 \mathrm{Al}_{2} \mathrm{O}_{3}+2 \mathrm{H}_{2} \mathrm{O} \rightarrow \mathrm{Na}_{3} \mathrm{KAl}_{4} \mathrm{Si}_{4} \mathrm{O}_{16}+4 \mathrm{HCl}
\end{gathered}
$$

In the presence of clinochlore additive, gehlenite, merwinite, and nepheline were generated according to equations (7), (8), and (13), respectively. Goethite was produced due to the absorption of moisture by hematite after ashing, whereas monticellite (MP $1503{ }^{\circ} \mathrm{C}$ ) [26] was synthesized following the reaction of lime of cardoon ash with $\mathrm{Mg}$ and $\mathrm{Si}$ incorporated in clinochlore:

$$
\mathrm{CaO}+\mathrm{MgO}+\mathrm{SiO}_{2} \rightarrow \mathrm{CaMgSiO}_{4}
$$

Leucite (MP $1600{ }^{\circ} \mathrm{C}$ ) [4] instead of kalsilite was found in this case and, additionally, the new phase merrihueite $\left(\mathrm{MP}>1300{ }^{\circ} \mathrm{C}\right)[26]$, through the reaction of sylvite and/or arcanite volatilized from cardoon ash up to $1200{ }^{\circ} \mathrm{C}$ with the magnesium silicate additive. The possible formation mechanisms are:

$$
\begin{gathered}
2 \mathrm{KCl}+4 \mathrm{SiO}_{2}+\mathrm{Al}_{2} \mathrm{O}_{3}+\mathrm{H}_{2} \mathrm{O} \rightarrow 2 \mathrm{KAlSi}_{2} \mathrm{O}_{6}+2 \mathrm{HCl} \\
\mathrm{K}_{2} \mathrm{SO}_{4}+4 \mathrm{SiO}_{2}+\mathrm{Al}_{2} \mathrm{O}_{3} \rightarrow 2 \mathrm{KAlSi}_{2} \mathrm{O}_{6}+\mathrm{SO}_{3} \\
2 \mathrm{KCl}+12 \mathrm{SiO}_{2}+5 \mathrm{MgO}+\mathrm{H}_{2} \mathrm{O} \rightarrow \mathrm{K}_{2} \mathrm{Mg}_{5} \mathrm{Si}_{12} \mathrm{O}_{30}+2 \mathrm{HCl} \\
\mathrm{K}_{2} \mathrm{SO}_{4}+12 \mathrm{SiO}_{2}+5 \mathrm{MgO} \rightarrow \mathrm{K}_{2} \mathrm{Mg}_{5} \mathrm{Si}_{12} \mathrm{O}_{30}+\mathrm{SO}_{3}
\end{gathered}
$$

In conclusion, these results show that the FT of cardoon with additives of either bauxite or clinochlore increased above $1500{ }^{\circ} \mathrm{C}$ due to the high melting point mineral phases produced upon ashing.

Regarding the straw ash, Table 6 shows that when bauxite or clinochlore was added, one new crystalline phase was generated, leucite, according to equations (15) and/or (16). Tables 5 and 6 show that sylvite and arcanite of straw evolved in the gas phase at $1200{ }^{\circ} \mathrm{C}$ and subsequently reacted with quartz and alumina. Thus, the FT of straw, $1515-1550{ }^{\circ} \mathrm{C}$ and $1404-1421{ }^{\circ} \mathrm{C}$ in the presence of bauxite and clinochlore, respectively, was attributed to the high sintering components of the additives, as well as those of straw, such as quartz (MP $\left.1700^{\circ} \mathrm{C}\right)$, mullite (MP $\left.1910{ }^{\circ} \mathrm{C}\right)$, and gehlenite (MP $\left.1593^{\circ} \mathrm{C}\right)[26,29]$.

For peach kernels ash (Table 5 and Table 6 ), leucite was formed that upon addition of bauxite via equations (15) and/or (16), or:

$$
2 \mathrm{KNO}_{3}+4 \mathrm{SiO}_{2}+\mathrm{Al}_{2} \mathrm{O}_{3}+\mathrm{H}_{2} \mathrm{O} \rightarrow 2 \mathrm{KAlSi}_{2} \mathrm{O}_{6}+2 \mathrm{HNO}_{3}
$$


In contrast, in the presence of clinochlore, lime produced from the decomposition of calcite and dolomite reacted with quartz to form wollastonite (MP $1510^{\circ} \mathrm{C}$ ) [24], which could be partly responsible for the lower FT with respect to raw ash:

$$
\mathrm{CaO}+\mathrm{SiO}_{2} \rightarrow \mathrm{CaSiO}_{3}
$$

The effect of additives, in this case, was to increase IDT and ST of peach kernels ash, as previously discussed.

The mineral phases of ashes, produced by the co-combustion of lignite with each biomass material at blending ratios 70:30, were the same as those identified in component fuels. Those in small amounts could hardly be detected. An example is shown in Figure 7. Apart from the complex reactions occurring during ash heating with mineral additives, the melting behavior of the ashes was affected by the dilution effect.

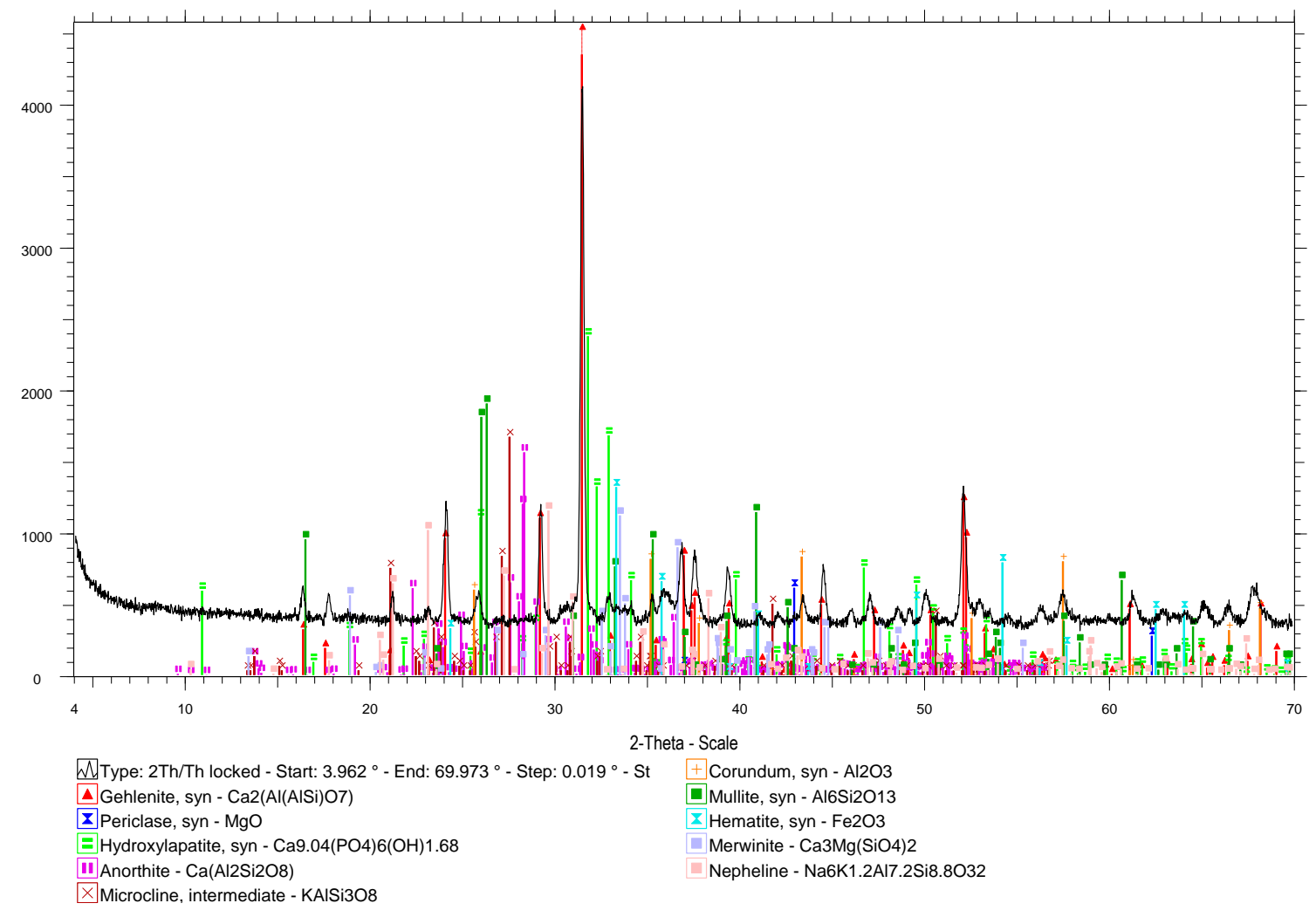

Figure $7 \mathrm{XRD}$ spectra of $\mathrm{ML} / \mathrm{CY}$ ash produced at $1200{ }^{\circ} \mathrm{C}$ in the presence of bauxite additive.

\section{Conclusions}

According to the ash fusibility test, the initial deformation and softening temperatures of biomass samples, ranging between $867{ }^{\circ} \mathrm{C}$ and $1253{ }^{\circ} \mathrm{C}$, were low for boilers operating above 900 ${ }^{\circ} \mathrm{C}$ due to their significantly higher concentration in $\mathrm{K}, \mathrm{Na}$, and $\mathrm{P}$ compounds. The deposition tendency increased as follows: $\mathrm{CY}>\mathrm{PEK}>\mathrm{SW}>\mathrm{ML}$. The behavior of lignite was reflected in its mixtures with the biomass materials. 
When the additives were mixed with raw fuels or lignite/biomass blends at percentages 3- to $5 \%$ and heated at a high temperature, the initial deformation temperature of ashes initiated at temperatures up to $340{ }^{\circ} \mathrm{C}$ higher, whereas the fluid temperature in most cases exceeded $1500{ }^{\circ} \mathrm{C}$. Clinochlore was less effective than bauxite. The positive impact of the additives was attributed to the mineralogical transformations during ashing to phases with a high melting point through reactions with $\mathrm{K}, \mathrm{Na}$-bearing minerals, or $\mathrm{CaO}$ of fuel ashes. Both bauxite and clinochlore could be used for reducing slagging/fouling propensity of these or similar fuels in combustion applications.

These results provide valuable information for the operation of lignite/biomass co-firing units relevant to the control of ash deposition in boilers. Although the mineralogical and chemical compositions of these ashes are linked to a low environmental impact following land disposal, further leaching tests and scaling-up of the process are required before any application.

\section{Acknowledgments}

The authors kindly thank the laboratories of Hydrocarbons Chemistry and Technology and Geochemistry, of the Technical University of Crete, for the ultimate analysis and XRF analysis.

\section{Additional Materials}

The following additional materials are uploaded at the page of this paper.

1. Figure S1: XRD spectra of (a) CY, (b) SW, (c) PEK and (d) $\mathrm{ML}$ ashes produced at $550^{\circ} \mathrm{C}$ and $1200^{\circ} \mathrm{C}$.

\section{Author Contributions}

D. Vamvuka: concept, writing, evaluation; M. Deli: experiments; A. Stratakis: XRD analysis and evaluation.

\section{Competing Interests}

The authors have declared that no competing interests exist.

\section{References}

1. International Energy Agency. Renewables 2018. Analysis and forecasts to 2023. Paris: International Energy Agency; 2018.

2. Vamvuka D. Biomass, bioenergy and the environment. Salonica: Tziolas Publications; 2009.

3. Mack R, Kuptz D, Schön C, Hartmann H. Combustion behavior and slagging tendencies of kaolin additivated agricultural pellets and of wood-straw pellet blends in a small-scale boiler. Biomass Bioenergy. 2019; 125: 50-62.

4. Wang L, Skreiberg O, Becidan M, Li H. Investigation of rye straw ash sintering characteristics and the effect of additives. Appl Energy. 2016; 162: 1195-1204.

5. European Commission. Circular economy action plan. Brussels: European Commission; 2020.

6. Toscano G, Feliciangeli G, Rossini G, Fabrizi S, Pedretti E, Duca D. Engineered solid biofuel from herbaceous biomass mixed with inorganic additives. Fuel. 2019; 256: 115895. 
7. Li F, Yu B, Li J, Wang Z, Guo M, Fan H, et al. Exploration of potassium migration behavior in straw ashes under reducing atmosphere and its modification by additives. Renew Energy. 2020; 145: 2286-2295.

8. Míguez JL, Porteiro J, Behrendt F, Blanco D, Patiño D, Dieguez-Alonso A. Review of the use of additives to mitigate operational problems associated with the combustion of biomass with high content in ash-forming species. Renew Sust Energ Rev. 2021; 141: 110502.

9. Roberts L, Mason P, Jones J, Gale W, Williams A, Hunt A, et al. The impact of aluminosilicatebased additives upon the sintering and melting behavior of biomass ash. Biomass Bioenergy. 2019; 127: 105284.

10. Stam AF, Brem G. Fouling in coal-fired boilers: Biomass co-firing, full conversion and use of additives-A thermodynamic approach. Fuel. 2019; 239: 1274-1283.

11. De Fusco L, Boucquey A, Blondeau J, Jeanmart H, Contino F. Fouling propensity of highphosphorus solid fuels: Predictive criteria and ash deposits characterisation of sunflower hulls with $\mathrm{P} / \mathrm{Ca}$-additives in a drop tube furnace. Fuel. 2016; 170: 16-26.

12. Garcia-Maraver A, Mata-Sanchez J, Carpio M, Perez-Jimenez JA. Critical review of predictive coefficients for biomass ash deposition tendency. J Energy Inst. 2017; 90: 214-228.

13. Vamvuka D, Sfakiotakis $S$, Mpoumpouris A. Slagging and fouling propensities of ashes from urban and industrial wastes. Recent Innov Chem Eng. 2018; 11: 145-158.

14. Wei $B$, Wang $X$, Tan $H$, Zhang $L$, Wang $Y$, Wang Z. Effect of silicon-aluminum additives on ash fusion and ash mineral conversion of Xinjiang high-sodium coal. Fuel. 2016; 181: 1224-1229.

15. Yao X, Zhou H, Xu K, Xu Q, Li L. Evaluation of the fusion and agglomeration properties of ashes from combustion of biomass, coal and their mixtures and the effects of $\mathrm{K}_{2} \mathrm{CO}_{3}$ additives. Fuel. 2019; 255: 115829.

16. Clery D, Mason P, Rayner C, Jones J. The effects of an additive on the release of potassium in biomass combustion. Fuel. 2018; 214: 647-655.

17. Kalisz S, Ciukaj S, Mroczek K, Tymoszuk M, Wejkowski R, Pronobis M, et al. Full-scale study on halloysite fireside additive in 230t/h pulverized coal utility boiler. Energy. 2015; 92: 33-39.

18. Dragutinovic N, Nakomcic-Smaragdakis B, Djuric S, Djordjic D. Investigation of additives in combustion of wheat straw pellets in a small scale boiler. J Renew Sustain Energy. 2019; 11: 043101.

19. Roni MS, Chowdhury S, Mamun S, Marufuzzaman M, Lein W, Johnson S. Biomass co-firing technology with policies, challenges, and opportunities: A global review. Renew Sust Energ Rev. 2017; 78: 1089-1101.

20. Vamvuka D, Trikouvertis M, Pentari D, Alevizos G, Stratakis A. Characterization and evaluation of fly and bottom ashes from combustion of residues from vineyards and processing industry. J Energy Inst. 2017; 90: 574-587.

21. Kloprogge JT, Ruan HD, Frost RL. Thermal decomposition of bauxite minerals: Infrared emission spectroscopy of gibbsite, boehmite and diaspore. J Mater Sci. 2002; 37: 1121-1129.

22. Villieras F, Yvon J, Cases JM, De Donato P, Lhote F, Baeza R. Development of microporosity in clinochlore upon heating. Clays Clay Miner. 1994; 42: 679-688.

23. Konsomboon S, Pipatmanomai S, Madhiyanon T, Tia S. Effect of kaolin addition on ash characteristics of palm empty fruit bunch (EFB) upon combustion. Appl Energy. 2011; 88: 298305. 
24. Llorente MF, Arocas PD, Nebot LG, García JC. The effect of the addition of chemical materials on the sintering of biomass ash. Fuel. 2008; 87: 2651-2658.

25. Sfakiotakis S. Study on the exploitation of agricultural, urban and industrial wastes of Crete for power production-thermal and kinetic analyses. Chania: Technical University of Crete; 2016.

26. Zalba B, Marín JM, Cabeza LF, Mehling H. Review on thermal energy storage with phase change: Materials, heat transfer analysis and applications. Appl Therm Eng. 2003; 23: 251283.

27. Yao X, Zhou H, Xu K, Xu Q, Li L. Investigation on the fusion characterization and melting kinetics of ashes from co-firing of anthracite and pine sawdust. Renew Energ. 2020; 145: 835846.

28. Lu Y, Wang Y, Xu Y, Li Y, Hao W, Zhang Y. Investigation of ash fusion characteristics and migration of sodium during co-combustion of Zhundong coal and oil shale. Appl Therm Eng. 2017; 121: 224-233.

29. Niu Y, Gong Y, Zhang X, Liang Y, Wang D. Effects of leaching and additives on the ash fusion characteristics of high- $\mathrm{Na} / \mathrm{Ca}$ Zhundong coal. J Energy Inst. 2019; 92: 1115-1122.

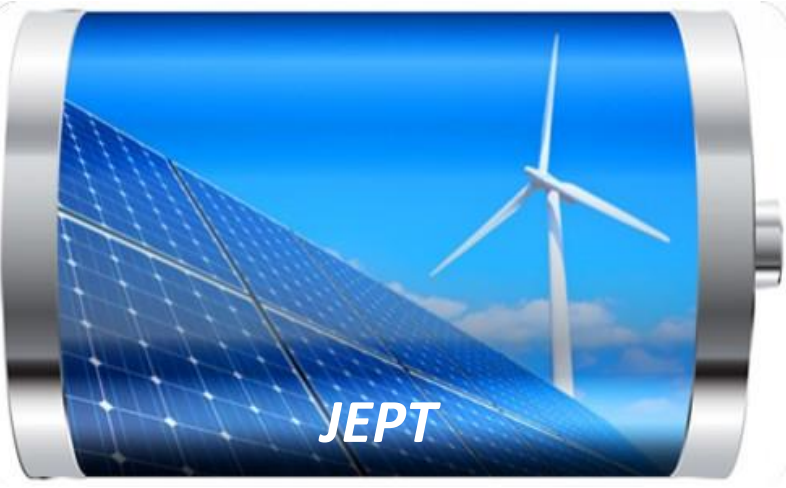

Enjoy JEPT by:

1. Submitting a manuscript

2. Joining in volunteer reviewer bank

3. Joining Editorial Board

4. Guest editing a special issue

For more details, please visit:

http://www.lidsen.com/journal/jept 